\title{
In Search of the Module in the Architectural Design of the 'Hellenistic' House in Nea Paphos, Cyprus
}

\author{
AlEKSANDRA BRZOZOWSKA-JAWORNICKA, \\ ANNA KuBICKA-SOWIŃSKA
}

\begin{abstract}
Ancient Graeco-Roman architecture was designed with the application of mathematical harmony as a key compositional principle used in planning the dimensions and proportions of particular elements, larger parts of buildings or whole edifices. Therefore, application of metrology studies based on a cosine quantogram supports architectural analysis leading to an indication of the predominant stylistic influence on any particular building. Such a dual approach helps to establish the origins of the major artistic tradition in architectural design, especially of buildings excavated in a complex multicultural archaeological context. The aim of this paper is to determine the existence and nature of a module in the architectural decoration as well as in the general design of the 'Hellenistic' House, a spacious residence in Nea Paphos, Cyprus, erected in Roman times, but according to the artistic Ptolemaic tradition.
\end{abstract}

Keywords: cosine quantogram, architectural module, metrology, 'Hellenistic' House, Nea Paphos, Cyprus

Aleksandra Brzozowska-Jawornicka, Faculty of Architecture, Wrocław University of Science and Technology, Wroclaw; aleksandra.brzozowska-jawornicka@pwr.edu.pl; (D) 0000-0003-0695-3016

Anna Kubicka-Sowińska, Faculty of Architecture, Wroclaw University of Science and Technology, Wrocław; Faculty of Geodesy and Cartography, Warsaw University of Technology, Warsaw;

anna.kubicka@pw.edu.pl; (D) 0000-0001-5442-3947

The study of ancient architecture may be conducted on the basis of various data: the layout of buildings, their structure and construction, architectural decoration, etc. The aim of this paper is to compare information obtained from traditional analysis of an examined edifice with a study of its metrological system of measures. Is it possible to determine what was the dominant influence affecting the design of a residence based on the major unit applied to building dimensions? This paper presents two different approaches to architectural analysis of the case study, namely the design of the 'Hellenistic' House, a rich peristyle residence situated in the southern part of the ancient city of Nea Paphos on the south-west coast of Cyprus (Fig. 1). 


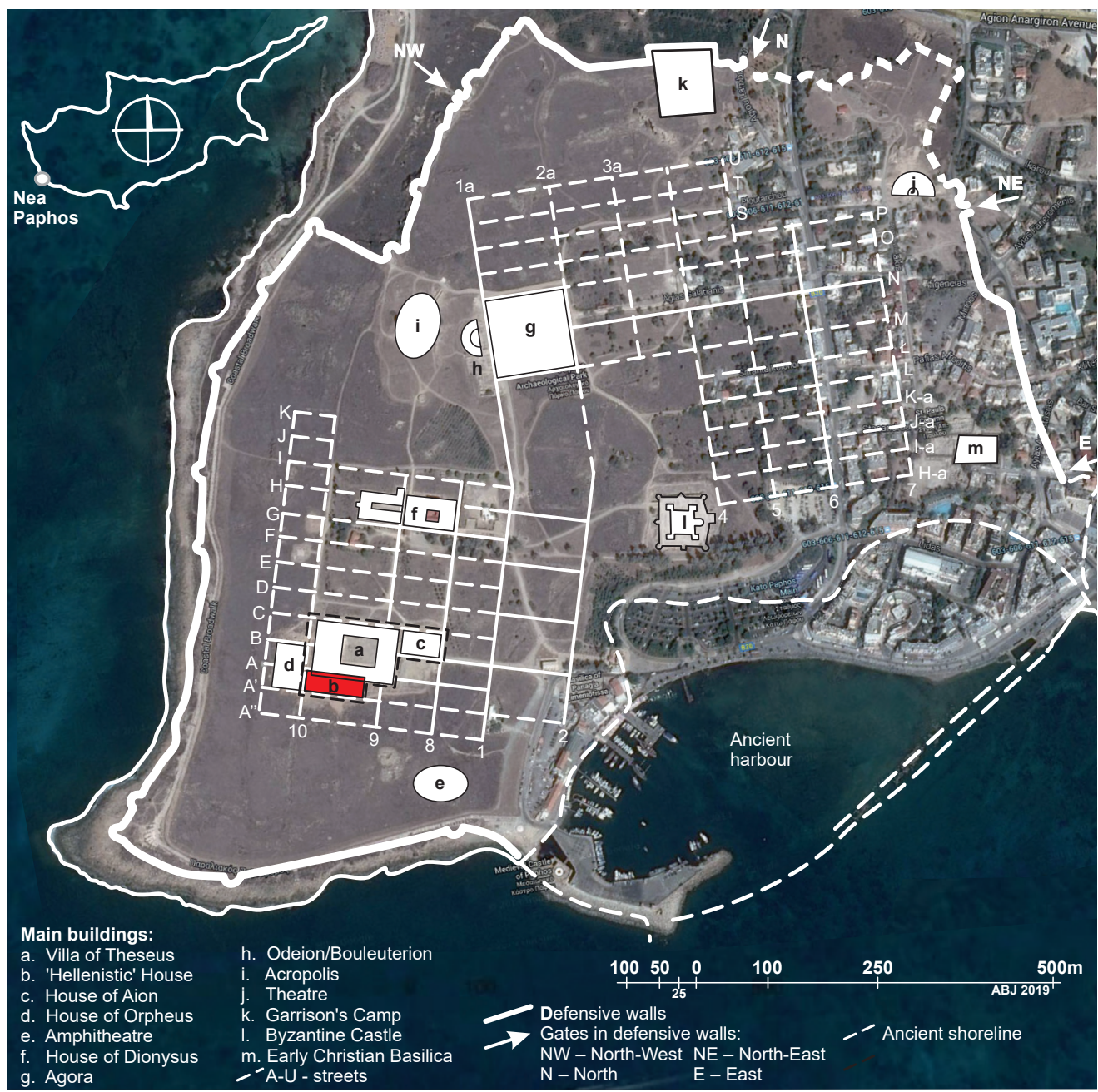

1. Plan of Nea Paphos (based on: Medeksza 1998: 37, Fig. 1; Młynarczyk 1990: 162, Fig. 16; retrieved from Google Earth, status as of October 5, 2014).

The 'Hellenistic' House was built at Maloutena - an area of the city with many extensive residences planned according to the Hellenistic grid of streets. The 'Hellenistic' House occupied the western part of the insula defined by streets A, A', 9 and 10 with the general dimensions of $30 \mathrm{~m}$ by $100 \mathrm{~m}$ (Figs 1-2). ${ }^{1}$ The residence was erected by the end of the first century $\mathrm{AD}^{2}$

1 Młynarczyk 1990: 163-164, 170-171.

${ }^{2}$ Initial discoveries, which included a mosaic of irregular fragments of pebbles in the main hall of the house, similar to the mosaics from the Hellenistic period, prompted the explorers to name the newly discovered edifice the Hellenistic House. Later studies revised this supposition: the house was built in the early Roman period, but the given name was already used and has been present in the literature since then. 
but was soon afterwards destroyed by an earthquake. ${ }^{3}$ After the fall of the 'Hellenistic' House, another residence, the Villa of Theseus, was built over the northern part of the earlier residence, ${ }^{4}$ which was never rebuilt.

In order to find out which architectural tradition in Cyprus - the Greek, the Ptolemaic, or the Roman - influenced the design of the 'Hellenistic' House to the greatest extent, complex studies of its layout and architectural embellishment were conducted and the results were compared with a statistical analysis of the set of building dimensions.

\section{CULTURAL INFLUENCES ON ARCHITECTURAL FORM OF THE HOUSE}

The design, layout and the decoration of the 'Hellenistic' House reflect the profusion of various influences present in Nea Paphos during the Hellenistic and Roman periods. Cyprus, under the impact of Greek as well as Middle East civilisations, had been ruled by local kings until it was conquered by Alexander the Great in 333 BC. After his death and the Wars of the Diadochi, which resulted in the division of his empire and the short reign of Demetrius I Poliorcetes on Cyprus, the island became part of the Ptolemaic Kingdom in the third century BC. Cyprus start to be an overseas territory of Egypt, with Nea Paphos serving as its capital. Strong links between the Ptolemaic Empire, especially its capital Alexandria, and Cyprus turned out to be crucial for the development of art and architecture on the island. The next change occurred on Cyprus with the appearance of the Romans in 58 BC. The island was incorporated into the Roman Empire and Nea Paphos held the position of one of the most important Cypriot cities with the palace, currently called the Villa of Theseus, possibly belonging to the Roman governor of the island. ${ }^{5}$ The presence of the Roman authorities left its mark on Cyprus in terms of its art and architecture, among other things.

The 'Hellenistic' House was designed around several courtyards, two of which were distinguished by a rich architectural arrangement (Fig. 2). ${ }^{6}$ The Main Courtyard, situated in the central part of the house, was erected in the form of a spacious peristyle occupying almost the whole width of the edifice. ${ }^{7}$ The smaller courtyard, located on the western side of the residence, was an almost square atrium - a tetrastylos. ${ }^{8}$ The layout of the house, with combinations of two major courtyards, shows the influences of two cultures. The peristyle house is considered to be a Greek invention, developed in the Hellenistic era, and widely propagated throughout the Graeco-Roman world. ${ }^{9}$ This design became popular on Cyprus most probably thanks to strong links with Ptolemaic Alexandria. On the other

\footnotetext{
${ }^{3}$ Meyza et al. 2017.

${ }^{4}$ Daszewski 1985; Daszewski, Michaelides 1988: 53; Medeksza 1998: 25; Meyza et al. 2017.

5 Daszewski 1985; Daszewski, Michaelides 1988: 53; Medeksza 1998: 25.

${ }^{6}$ For an analysis of the architecture of the 'Hellenistic' House, see: Brzozowska-Jawornicka 2021.

7 Daszewski 1991: 82; Meyza et al. 2014.

${ }^{8}$ Brzozowska 2016: 46-51; Brzozowska-Jawornicka 2018.

${ }^{9}$ Hales 2003: 208-209; Morvillez 2018: 19-20, 30; Nielsen 1994: 24-26.
} 


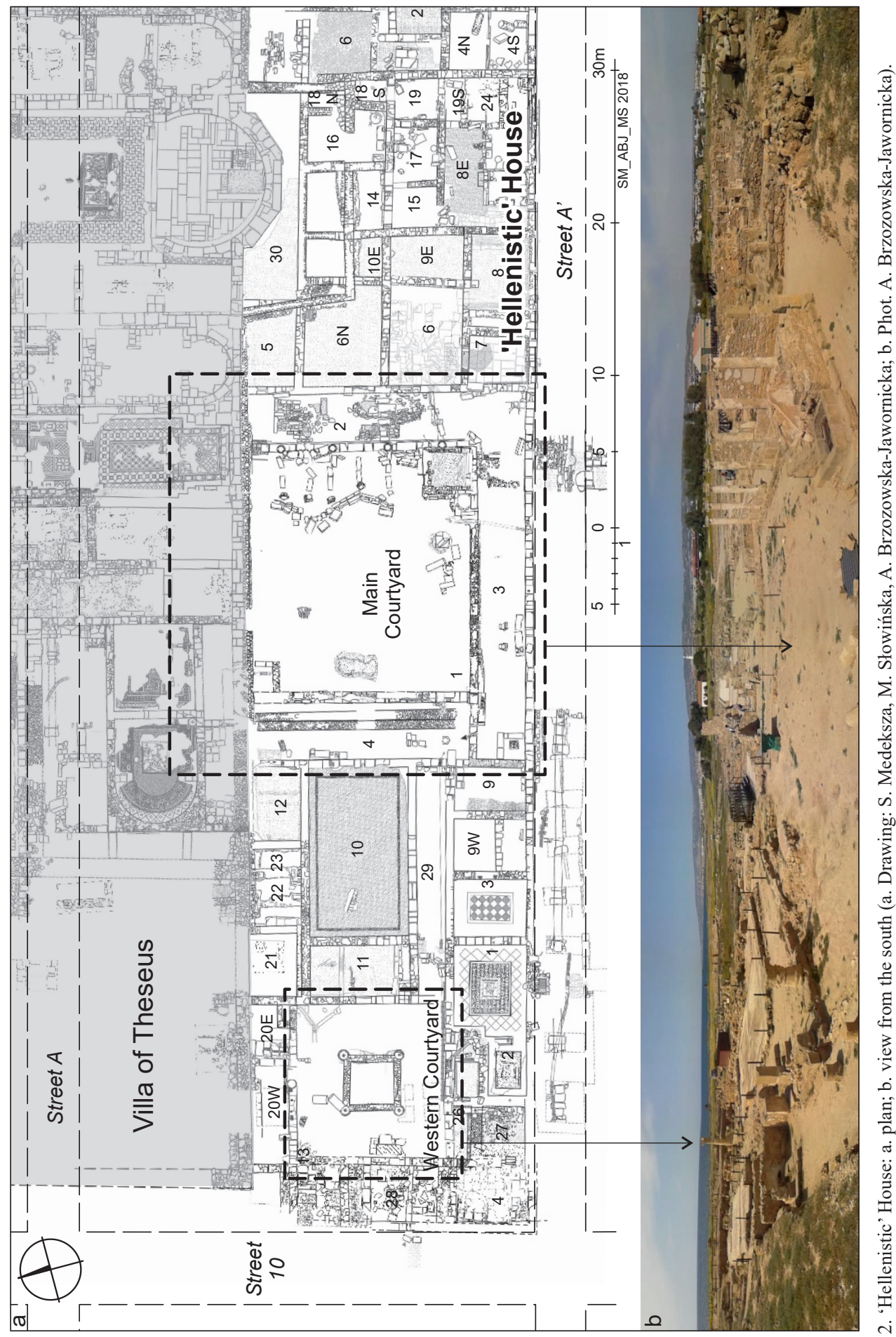




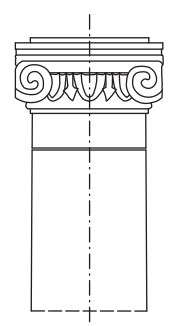

Eastern Portico

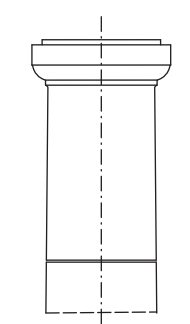

Southern Portico

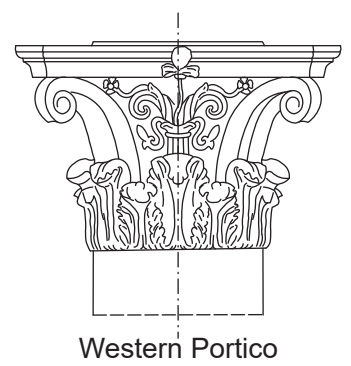

Western Portico

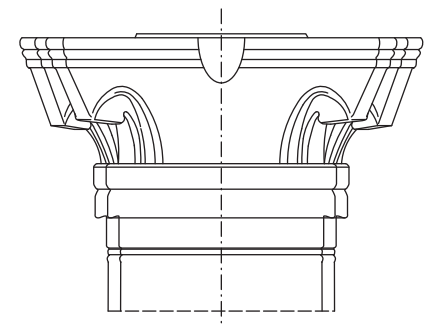

Northern Pseudo-portico

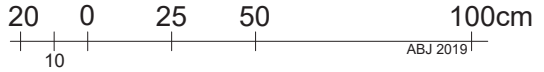

3. Architectural orders of the Main Courtyard of the 'Hellenistic' House (Drawing: A. Brzozowska-Jawornicka).

hand, the atrium is a Roman creation used as a key part of the residence entrance zone. ${ }^{10}$ The tetrastylos of the 'Hellenistic' House is situated close to street 10, but no clear signs of entrance were found in this area, perhaps due to the poorly preserved relics of the walls. Houses with both an atrium and a peristyle are known throughout the Roman Empire. ${ }^{11}$

The architectural decoration of the 'Hellenistic' House attests to its owner's interest in the newest trends in art and architecture. The embellishment of the residence is very rich: among the two courtyards mentioned above, five different architectural orders were used. The wealth and variety of the adornment seem to be compatible with Roman taste, although the styles and types of architectural elements clearly show Alexandrian provenance. In terms of architectural orders and scale, the main courtyard was composed of four different porticoes (Fig. 3). Two lower ones were erected on the eastern and southern sides of the peristyle: Ionic ${ }^{12}$ and Doric respectively. ${ }^{13}$ They were most probably topped with another storey, which would have made them the same height as the other two much higher porticoes, the western and northern ones. The latter two were erected in the most elaborated architectural orders. The western colonnade was Corinthian ${ }^{14}$ in a special variation called the Alexandrian style. ${ }^{15}$ The northern side of the Main Courtyard was completely destroyed by the earthquake and the subsequent erection of the Villa of Theseus. Nevertheless, archaeological excavations conducted in the area of the court and architectural studies enabled us to establish the form of the northern part of the peristyle. It turned out that it was a pseudo-portico composed of several engaged supports of a very complex form: a half-column with a pilaster. The supports were crowned with capitals of a simplified geometrised shape originating from the Corinthian capital. They were identi-

${ }^{10}$ Hales 2003: 153-154.

${ }^{11}$ Hales 2003: 97-134, 167-247.

${ }^{12}$ Daszewski 1992a: 251-253; Daszewski, Sztetyłł 1988: 199; Karageorghis 1988: 835; 1989: 834-835.

${ }^{13}$ Daszewski 1992a: 253; 1992b: 65.

${ }_{14}$ Daszewski 1990: 35; 1992b: 253-254; Papageorghiou 1990: 997, Fig. 97.

${ }_{15}$ McKenzie 1990: 64-96; 2007: 84-87, Figs 121, 125-126, 128-135; Pensabene 1993: 109-120, Pls 26-42; Ronczewski 1927. 
fied as the so-called blocked-out capitals ${ }^{16}$ resembling Nabataean capitals type 1, known primarily from Petra. ${ }^{17}$ According to the most recent studies, such capitals were also invented in Ptolemaic and Roman Alexandria and then spread across the eastern part of the Graeco-Roman world, especially in Egypt, Nabataea and on Cyprus. ${ }^{18}$ The form of the northern side of the courtyard, the pseudo-portico instead of a portico, reflects the transformation of the form of the courtyard from a classical peristyle into a pseudo-peristyle. It is another feature characteristic of Alexandrian architecture - e.g. the layouts of the houses in the Kom el-Dikka area were often designed with a pseudo-peristyle in the central part of the residence. ${ }^{19}$ Such an arrangement was usually due to a scarcity of space. ${ }^{20}$ Unfortunately, the extent of destruction of the Main Courtyard in the 'Hellenistic' House prevents us from establishing the construction and form of the entablatures crowning its porticoes.

The second, smaller, courtyard of the 'Hellenistic' House, an atrium located in the western part of the edifice, was designed, as mentioned above, in a form of a tetrastylos composed of four columns topped with pseudo-Ionic capitals. ${ }^{21}$ Such capitals are very rare - they are present in only a few buildings in Nabataea. Similarly to the blocked-out capitals originating from the Corinthian order, the pseudo-Ionic ones are derived from a particular type of Ionic capital with four corner volutes. ${ }^{22}$ The columns of the tetrastylos were surmounted with a complex tri-partite entablature. ${ }^{23}$ There are no fragments that could be identified as remains of an architrave, which was most probably made of wood. A slightly simplified version of a Doric frieze with triglyphs and plain metopes constituted the middle part of the entablature. A Corinthianising cornice with flat grooved modillions alternating with square hollow modillions crowned the whole structure. Such a cornice is considered to be another feature of a purely Alexandrian style, as is the idea of mixing various orders, usually a Doric frieze with an Ionic or Corinthian cornice, in one architectural ensemble. ${ }^{24}$ These attributes of Alexandrian architecture are also widely attested throughout the Eastern Mediterranean. ${ }^{25}$

\section{ANCIENT MEASUREMENT SYSTEMS}

Apart from analysis of spatial arrangements and architectural decoration, the modern understanding of ancient architecture design may be based also on identification of the system

${ }_{16}$ Brzozowska 2016: 61-62; Meyza 2015: 450-451.

${ }_{17}$ McKenzie 1990: 117, Diagram 14g, 17, Pls 106, 109, 112, 138-139, 141, 144-146, 159-160.

${ }^{18}$ Czerner 2009: 2, 6-12, Figs 5-11, 15-16, 38, 53-57, 59, 112, Pls I-III, VI-VII.

19 Majcherek 1995: 11-20, Figs 1-2; 1997: 13-15; 2000: 32-34, Fig. 5; McKenzie 2007: 150, 180-183, 210, Figs 309-310.

${ }^{20}$ Hales 2003: 153; Jashemski 1993: 38-41.

${ }^{21}$ Brzozowska-Jawornicka 2018.

${ }^{22}$ McKenzie 1990: 159-165, Pls 138-139, 141c, 145-146, 149a-c.

${ }^{23}$ Meyza et al. 2012: 414.

${ }^{24}$ Brzozowska-Jawornicka 2021: 105, 111, Figs 6-7, 9.

${ }^{25}$ McKenzie 1990: 93-94, Pls 26b, 39a-b, 119a, 222; 2007: 58, Figs 74, 65, 87-89, 91, 94b, 139-140; Pensabene 1993: 92-103, 131-133, 135; Pesce 1950; Stucchi 1975; Wright 1992: 47, Fig. 2. 
of linear measurements utilised at the time. Based on cultural influences on Cyprus during the Graeco-Roman period, we can indicate three possible standards of the measurement applied in the design of the 'Hellenistic' House: the Greek, the Ptolemaic, and the Roman standardisations (Table 1).

Table 1. Comparison of three basic units of measure: a palm, a foot and a cubit in three systems of measurement

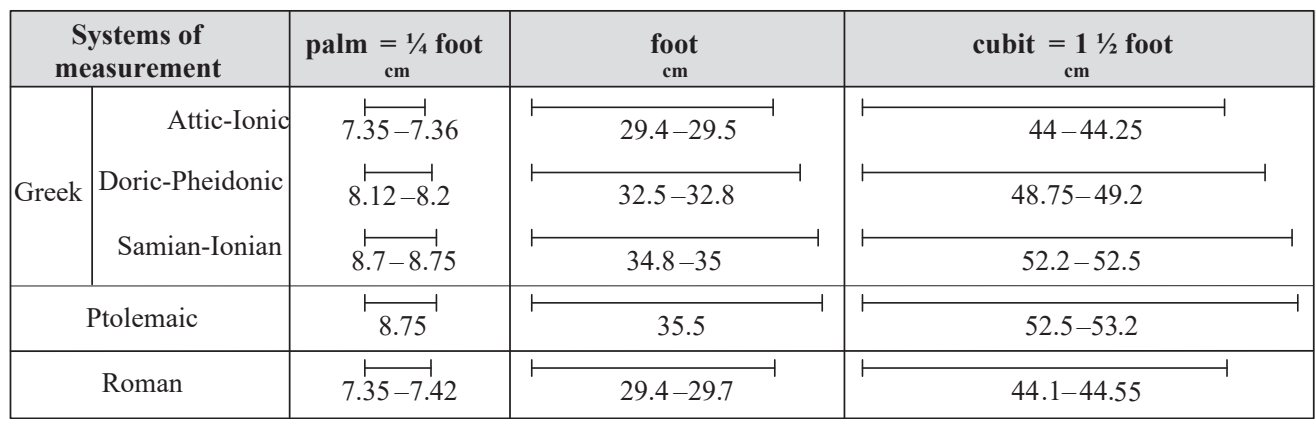

According to Herodotus, different foot lengths were in use in the Greek world, and some of the relations among various units of measurement were described in his work. ${ }^{26}$ Contemporary studies also confirm that certain regions of Greece used particular units of length, usually with the basic module of a foot. These various Greek feet varied over time and space. They were categorised into three main systems of measurement: the Attic-Ionic foot $(29.4-29.5 \mathrm{~cm})$, the Doric-Pheidonic (influenced by the Egyptian cubit; $32.5-32.8 \mathrm{~cm}$ ), and the Samian-Ionian $(34.8-35 \mathrm{~cm}){ }^{27}$

The second possible design pattern of the 'Hellenistic' House is related to the strong influence of Hellenistic culture from the Ptolemaic Egypt, and, as mentioned above, had a very strong impact on Cypriot architecture, e.g. the layouts of residences and architectural decoration. The Ptolemaic cubit is a combination of three metrological standards: the Greek, the Hellenistic introduced after the expedition of Alexander the Great into Asia, and the reformed cubit of the Twenty-sixth Dynasty of Egypt. ${ }^{28}$ The Ptolemaic standard measure was the Great Ptolemaic foot: approx. $35.5 \mathrm{~cm}$.

After nearly 250 years of Ptolemaic rule Cyprus was incorporated into the Roman Empire. The well-documented Roman foot standard, measuring 29.4-29.7cm, ${ }^{29}$ was preserved on the island on the mosaic showing Ktisis in the Baths of Eustolios in Kourion (Fig. 4). The meaning of this motif is related to the erection of actual buildings, the Baths and Annex in the late fourth century AD. ${ }^{30}$

An analogical representation of Ktisis, as an act of a generous donation and foundation, was placed on a Byzantine mosaic from the fifth century AD and is presently displayed

\footnotetext{
26 Hdt. 6.127.3.

27 Dinsmoor 1961: 355-368; Dörpfeld 1890: 167-197; Müller-Wiener 2004: 33-34; Riemann 1935: 1-6.

${ }^{28}$ Hirsch 2013: 148-150.

${ }^{29}$ Wilson-Jones 2000: 73-74.

${ }^{30}$ Mitford 1971: 358-359.
} 


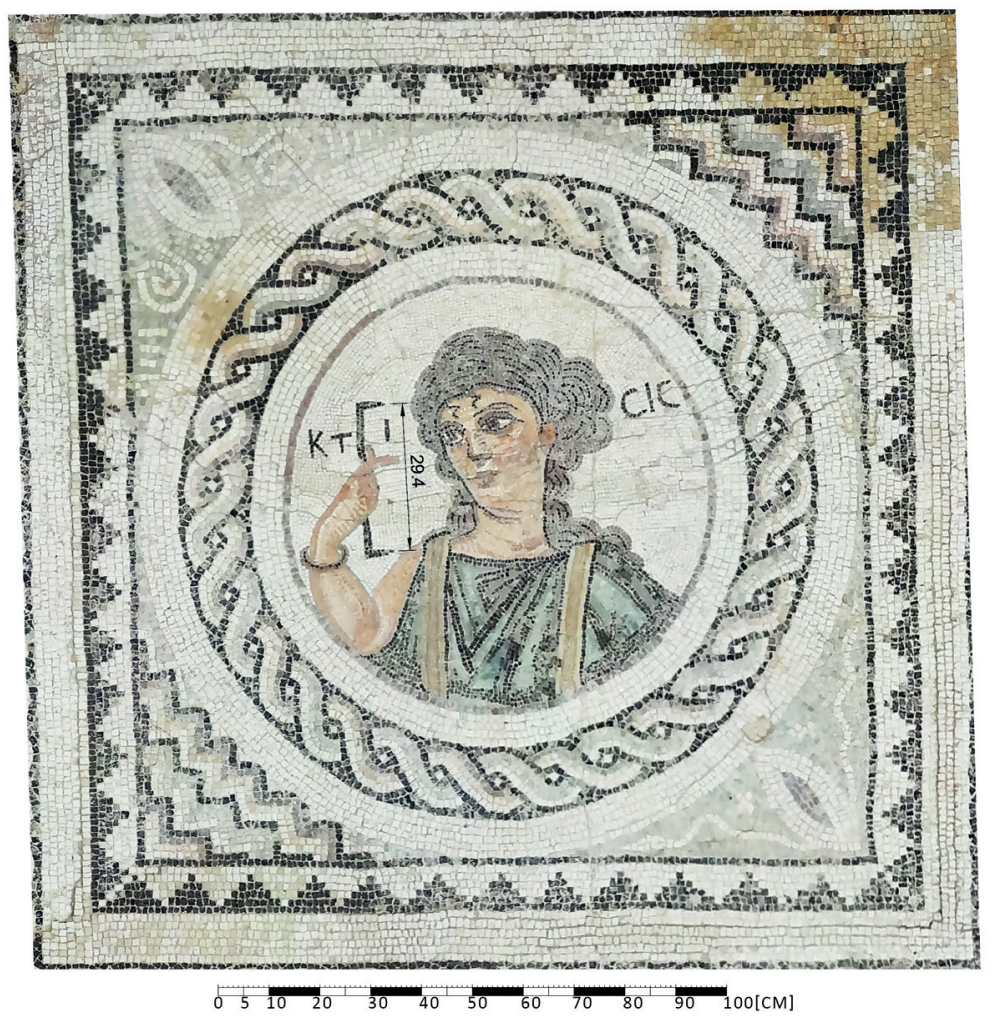

4. Woman, identified as Ktisis, holding measuring tool of the Roman foot $(29.4-29.7 \mathrm{~cm})$, in the mosaic of Kourion (based on: Charalambous 2012: 436, Fig. 216; courtesy of E. Charalambous; scaled based on measurements taken by A. Kubicka-Sowińska).

in the Metropolitan Museum of Art in New York (Fig. 5). In both examples a measuring tool is depicted in actual size and has the form of a metal rod, the approximate size of the Roman foot. The dimensions of the metal rods as around $29.4-29.7 \mathrm{~cm}$ were confirmed on both mosaics. In order to do that, mosaics were photographed with the dimension's markers and 3D modelling was performed in the software for close range photogrammetry (Agisoft).

\section{DATA CHARACTERISATION AND THE METHOD OF METROLOGICAL STUDIES}

This study attempts to define a module or a metrological unit of unknown size applied in the 'Hellenistic' House on the basis of an analysis of a set of dimensions. If a design unit of a certain size, or a quantum in statistical terms, was implemented into the building plan and/or into various elements of its architectural design, it should be possible to detect it by statistically analysing the building's measurements. By identifying this unit, it may also be possible to trace the source of the applied system of measures, a region or a city, etc., and in consequence the dominant architectural influence on the building. 


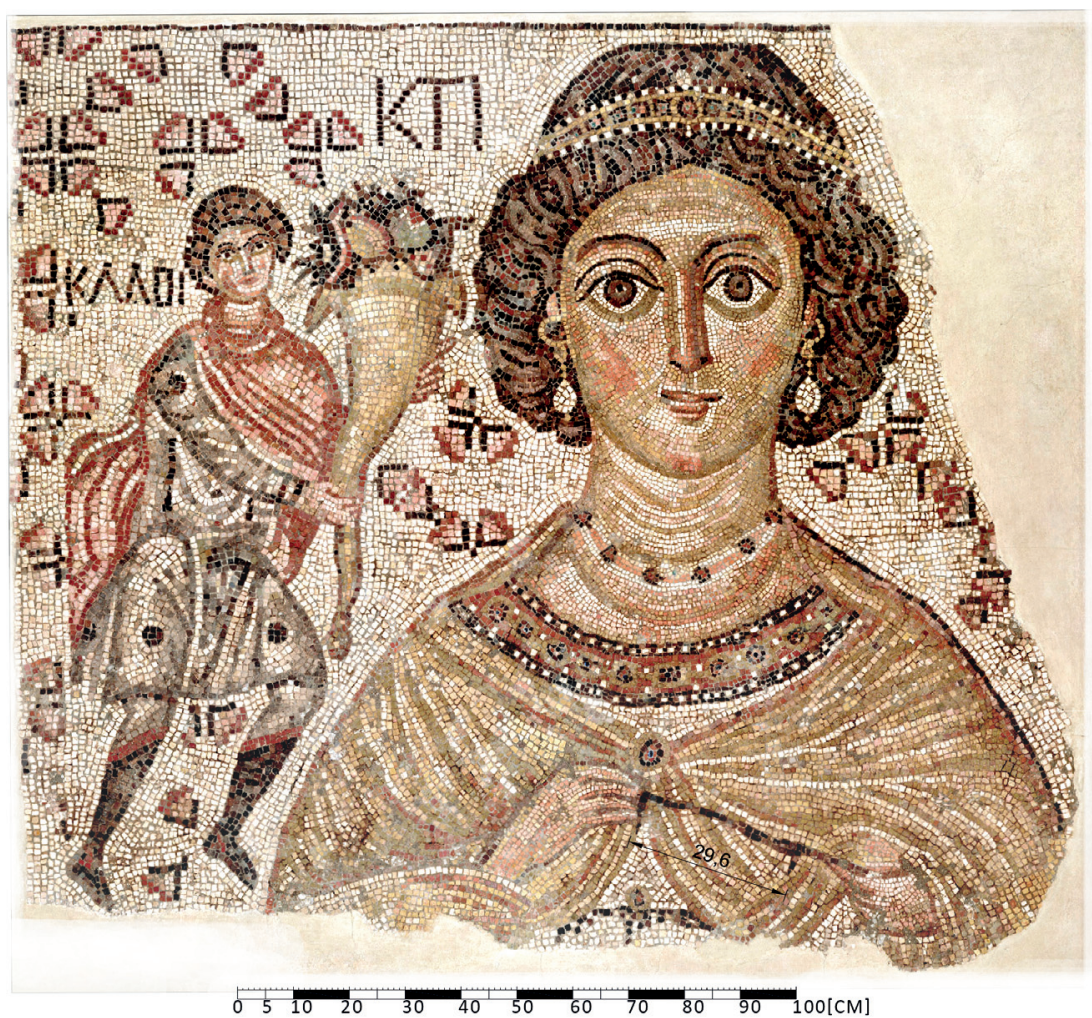

5. Woman, identified as Ktisis, holding measuring tool of the Roman foot $(29.4-29.7 \mathrm{~cm})$, in the Byzantine mosaic from the Metropolitan Museum of Art (based on: The Metropolitan Museum of Art 2012: 181; scaled based on measurements taken by A. Kubicka-Sowińska).

External influences in the architectural design of the 'Hellenistic' House will be examined in terms of the relationship between its design, decoration and the applied system of measures. Such a metrological analysis requires a multipart set of repeatable elements. As mentioned above, most of the house was heavily destroyed by earthquakes, but the state of preservation of its Western Courtyard, erected in the form of a tetrastylos with an impluvium in the middle, ${ }^{31}$ allows precise reconstruction along with an entablature surmounting four columns. The preserved elements from the entablature, in particular the frieze, constituted the set chosen for analysis (Fig. 6). The dataset - dimensions of certain parts of the frieze decoration juxtaposed together - was the basis for establishing the initially unknown design unit.

As already stated above, the entablature consisted of three parts: the presently unpreserved architrave, most probably wooden, the Doric frieze, and the Corinthianising cornice with modillions. The blocks constituting the frieze were $45 \mathrm{~cm}$ high and $28.5 \mathrm{~cm}$ wide.

31 Brzozowska-Jawornicka 2018. 


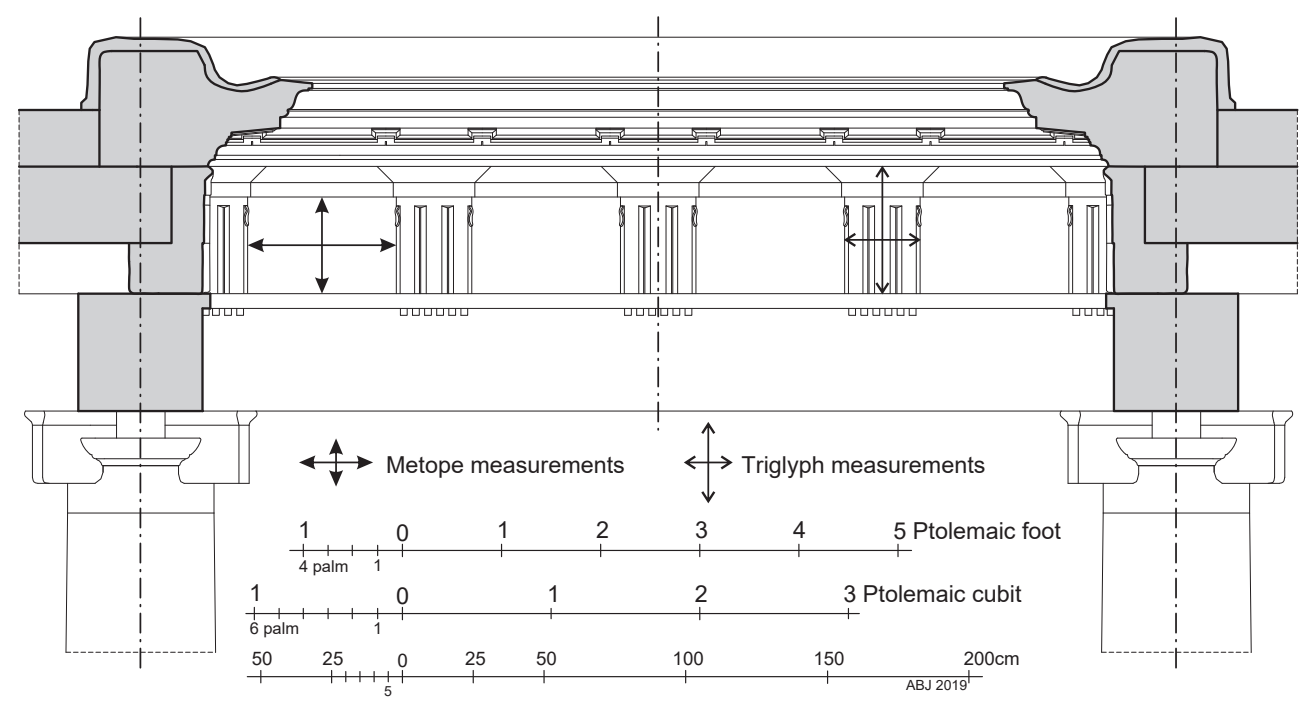

6. The reconstruction of the tetrastylos entablature from the 'Hellenistic' House with marked measurements taken for the metrological analysis (Drawing: A. Brzozowska-Jawornicka).

They were decorated with triglyph-metope continuous embellishment. ${ }^{32}$ The triglyphs were composed of three vertical mouldings crowned with a kind of a capital with an oblique cut-in profile. The triglyphs were separated from each other with plain rectangular metopes. The ratio of the widths of the triglyphs to metopes is more or less 2 to 1 . The proportions of the frieze elements differ from the classical canon described by Vitruvius. ${ }^{33}$ Other features of the frieze are also different from the classical Doric entablature: e.g. the lack of bottom elements in the form of a taenia, regulae or guttae. It is, however, possible that these elements from the frieze were incorporated into the unpreserved architrave. Similar simplified versions of the classical decoration may be found throughout the eastern Graeco-Roman world, such as in Petra or Egypt. ${ }^{34}$

In many cases ancient measurement systems are reconstructed on the basis of inscriptional or archaeological evidence of measuring tools. The strong impact in metrological analyses of ancient Greek architecture was asserted by Jari Pakkanen, ${ }^{35}$ who implemented a statistical methodology using cosine quantogram analysis to studies of ancient design.

The method used in this article is inspired by quantogram studies carried out using the cosine quantogram algorithm elaborated and then published by David George Kendall. ${ }^{36}$

The number of relevant measurements is usually limited in archaeological contexts due to damage to the analysed material. In the case of the 'Hellenistic' House, metrological

${ }^{32}$ Brzozowska-Jawornicka 2018: 61, 66-72, Figs 3, 6-8; Meyza et al. 2012: 414.

${ }^{33}$ Vitr., De arch. IV.2.

${ }^{34}$ McKenzie 2001: 103-105.

${ }^{35}$ Pakkanen 2002; 2013.

${ }^{36}$ Kendall 1974. 
analyses of building measurements were collected from the Doric frieze described above, chosen for this purpose because of the repeatability and uniformity of the triglyph-metope decoration. Nine blocks belonging to this part of the entablature were preserved in an appropriate condition to serve as a dataset with possible standardised measurements. Heights and lengths of the whole frieze in general and of the triglyphs and metopes in particular established a sample size of twenty-four dimensions (Table 2).

Table 2. The dimensions from the Doric frieze of the tetrastylos in the 'Hellenistic' House; dimensions come from archives (catalogue of architectural detail, 2009 and 2010) of the Polish Archaeological Mission of the University of Warsaw in Kato Paphos

\begin{tabular}{|l|l|l|}
\hline \multicolumn{1}{|c|}{ Block element } & \multicolumn{1}{|c|}{ Data-measurements $[\mathbf{c m}]$} & \multicolumn{1}{|c|}{ Dimensions } \\
\hline metope & $51.75,52.14,52.56$ & length \\
\hline triglyph & $26.37,26.34,26.2,25.02$ & length \\
\hline \multirow{2}{*}{ frieze } & $45.25,45.12,44.72,44.94,44.49,44.48,44.79$, & \multirow{2}{*}{ height } \\
\cline { 2 - 3 } & $34.2,34.86,34.63,35.02,34.54,34.54,33.2$ & height \\
\hline cornice & $16.99,15.81$ & \multicolumn{1}{|c|}{} \\
\hline
\end{tabular}

Any error in the set of measurements could be related to one of the following factors: the structure of the material, precision of stonework, the current state of preservation, and methods and tools of measurement used by the modern scholar who collected them. A difference of $1 \mathrm{~cm}$ between dimensions of similar relatively small architectural elements, such as frieze blocks, is common in Greek building practice. ${ }^{37}$ In the present studies, measurements used in the quantogram analyses were collected with a precision of $0.1 \mathrm{~cm}$ and calculated with the same step. The maximum value of searching quanta is $60 \mathrm{~cm}$, which includes the cubit measure as possible results.

\section{APPLICATION OF COSINE QUANTOGRAM IN METROLOGICAL ANALYSIS: RESULTS AND DISCUSSION}

If we assume that all the dimensions of architectural detail or construction elements were established based on a module standardised at that time, we can define each building's dimension as a multiplication of the module plus a small error - made during the stonework or construction phase. In order to find the value of the searched module (quantum) we applied the statistical method called cosine quantogram to establish the best candidate for quantum based on the series of collected measurements (see Appendix below).

The metrological analysis of dimensions of the frieze elements and the results of quantum $(q)$ estimation are presented on a line graph, where the highest peak, $8.8 \mathrm{~cm}$, is the best candidate for the basic unit, existing in a set of measurements (Fig. 7).

\footnotetext{
37 Coulton 1975: 94; Pakkanen 2013: 13.
} 


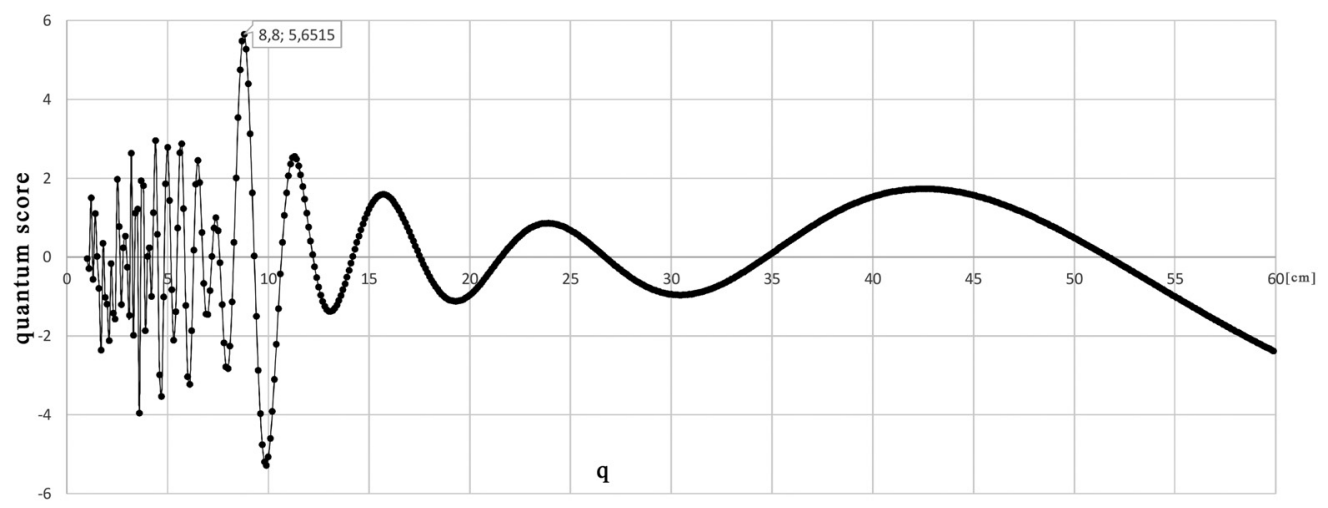

7. Cosine quantogram plot for the Doric frieze from the tetrastylos of the 'Hellenistic' House, listed in Table 1 (Processed by: A. Kubicka-Sowińska).

The cosine quantogram algorithm itself does not assume any potential value of a quantum or even premise its existence. Thus, without information from historical sources we can statistically prove the existence of a module in a set of data. However, historical information from written sources and/or analyses of architectural forms helps to understand the interpretation of such a module.

In the case of the 'Hellenistic' House, we could assume the presence of various standards of measurement described above, which could have been used for its design considering the time and place of its erection. However, the estimated quantum of $8.8 \mathrm{~cm}$, a result of the metrological research on the Doric frieze, fits into the four palms division of the Great Ptolemaic foot (approx. $35.5 \mathrm{~cm}$ ). The width of the triglyph is 3 palms $(26.4 \mathrm{~cm})$ and the width of the metope is 6 palms $(52.5 \mathrm{~cm})$. It seems that the Great Ptolemaic foot constituted the basic ancient module which could have been divided into four smaller parts - palms. In our calculations the palm appeared as the smallest indivisible unit, or in metrological terms, quantum.

The length of one Ptolemaic cubit equals one and a half Ptolemaic feet: $52.5-53.2 \mathrm{~cm} .{ }^{38}$ The reformed cubit and the royal cubit inherited by Ptolemais derived from Pharaonic Egypt have the same length but differ in the number of the palm divisions - there are six in the reformed cubit, each around $8.75-8.8 \mathrm{~cm}$, and seven in the royal cubit, each around $7.5 \mathrm{~cm} .{ }^{39}$

Didymus of Alexandria, the first-century BC scholar, described correlations between various units of length and the Ptolemaic cubit in his work 'The Measurement of Different Types of Timber'. The division of this unit is equal to 6 palms, 24 digits, 1.5 Ptolemaic feet, or $4 / 5$ of a Roman foot. Since the Ptolemaic foot $(2 / 3$ of a cubit, $52.5 \mathrm{~cm})$ was $35 \mathrm{~cm}$, and a Roman foot was defined as 5/6 of a Ptolemaic foot, then the Roman foot would be $29.2 \mathrm{~cm}$. The length of the Roman foot on surviving buildings in Italy varies, with an

\footnotetext{
38 Hirsch 2013: 78-82.

39 Iversen 1990; Zignani 2010: 158.
} 
average of $29.6 \mathrm{~cm} .{ }^{40}$ Whilst these calculations are largely given for timber, they are equally applicable to stone. The cubit measuring 1.5 Ptolemaic feet equals both the cutter cubit used by carpenters and the 'lithic cubit' used by stone masons and in quarries. ${ }^{41}$

The importance of the application of the principle of modular composition was explained by Vitruvius: the dimensions of a small element of the building, like the lower diameter of a column shaft or the width of the triglyph, were to be multiplied to determine the larger measurements of e.g. a colonnade or general building dimensions. ${ }^{42}$ This rule assured a mathematical harmony reflected in architectural forms. Therefore, using a multiplication of ancient foot-units, e.g. ten, twelve or one hundred feet, to design some larger elements or parts of ancient buildings was a natural and common practice, confirmed by recent metrological studies. ${ }^{43}$ Taking this into account, we checked whether the multiple of the Great Ptolemaic foot standard may be found in some larger measurements of the 'Hellenistic' House. The tetrastylos surmounted by the entablature containing the analysed Doric frieze constituted a natural choice. Its layout is almost square and the measurements of its intercolumnia presently vary from 354 to $365 \mathrm{~cm}$, most probably because of the damage caused by earthquakes..$^{44}$ If we assume that the lower value, $354 \mathrm{~cm}$, was the original, designated one, and the higher value, $365 \mathrm{~cm}$, was a result of some seismic displacement, we can indicate the multiple of the basic measurement unit used for the tetrastylos planning: ten times the Great Ptolemaic foot: 10 x $35.5=355 \mathrm{~cm}$.

The established design unit of the 'Hellenistic' House, the Great Ptolemaic foot used for designing both the relatively small elements of the architectural decoration, such as the Doric frieze, as well as the whole structures like the tetrastylos, confirms the dominant artistic influence of Ptolemaic architecture, in particular the so-called Alexandrian style in the Graeco-Roman residences of Nea Paphos.

\section{CONCLUSIONS}

The origins of architectural influences have so far been primarily noticed in the architectural studies of the style and the construction of the Western Courtyard..$^{45}$ According to that study, the reconstructed tetrastylos combines the classical canon with the so-called Alexandrian style that originated in the Ptolemaic Kingdom. The stylistic analysis is now supplemented with further metrological study. The application of the cosine quantogram in studies on building measurements of the 'Hellenistic' House revealed connections with the Ptolemaic system of measures in residence design. It seems that both analytical approaches, the first examining the layout and the decoration of the 'Hellenistic' House,

\footnotetext{
40 Didymus of Alexandria II.29, V.46.

${ }^{41}$ McKenzie 2007: 326.

${ }^{42}$ Vitr., De arch. III.6.

${ }^{43}$ Pakkanen 2004: 111-121; Hellmann 2002: 44-39.

${ }^{44}$ Meyza et al. 2014.

${ }^{45}$ Brzozowska-Jawornicka 2018; 2021: 104-108.
} 
and the second investigating the system of measurement applied to building dimensions, prove the very strong influences of Alexandria at the time of the House's erection. Such impacts have been already observed in other Cypriot edifices ${ }^{46}$ and throughout the eastern Mediterranean region, confirming the absolute artistic domination of the Egyptian capital in the Graeco-Roman period. It is worth emphasising that the influence of Egypt on Cypriot art and architecture did not cease after the Roman conquest but was still present on the island for the following few centuries. The 'Hellenistic' House, built several decades after the arrival of the Romans at Nea Paphos, is a perfect example of this trend.

The comparison and juxtaposition of both approaches applied in the analysis of the architecture of the 'Hellenistic' House prove that metrological analysis constitutes a verified and useful tool for the classical studies of architecture.

\section{APPENDIX: STATISTICAL METHODS USED IN THE MODULE CALCULATION}

Metrological analysis of Graeco-Roman architecture is based on searching for the smallest unit of measurement that could exist in the dimensions of each element of the building. In order to find the smallest unit (quantum), a series of collected measurements were analysed with the cosine quantogram function, and the results were evaluated by the Monte Carlo simulation. ${ }^{47}$

Considering each of these dimensions: $X$ as a result of an integral multiple $M$ times the quantum $q$ plus an error component $\varepsilon$, we can define in mathematical terms a block dimension as (1):

$$
X_{i}=M_{i} q+\varepsilon_{i}
$$

The error factor is essential in the formula (2). This formula calculates a number of errors in measurements which clusters around $q$ or 0 . The value of $\varepsilon$ is a result of the division of the measure $X$ by $q$ and then the cosine of $\varepsilon / q$ is taken. It gives a value of +1 for dimensions $X$ which are multiples of $q$, and badly fitting measurements generate a value of -1 . In order to find out which $q$ is the best candidate for quantum all measurements are computed in the cosine quantogram.

To calculate the quantum score the following function of Kendall's cosine quantogram was used:

$$
f(q)=\sqrt{\frac{2}{N}} \sum_{i=1}^{N} \cos \left(\frac{2 \pi X_{i}}{q}\right)
$$

Where: $\mathrm{N}$ is the number of measurements, $\sqrt{\frac{2}{n}}$ is the scaling factor, dependent on the sample size and $\cos \left(\frac{2 \pi X_{i}}{q}\right)$ is the quantity proportional to the von Mises probability

\footnotetext{
46 Guimier-Sorbets, Michaelides 2009.

${ }^{47}$ Kasiński 2019.
} 


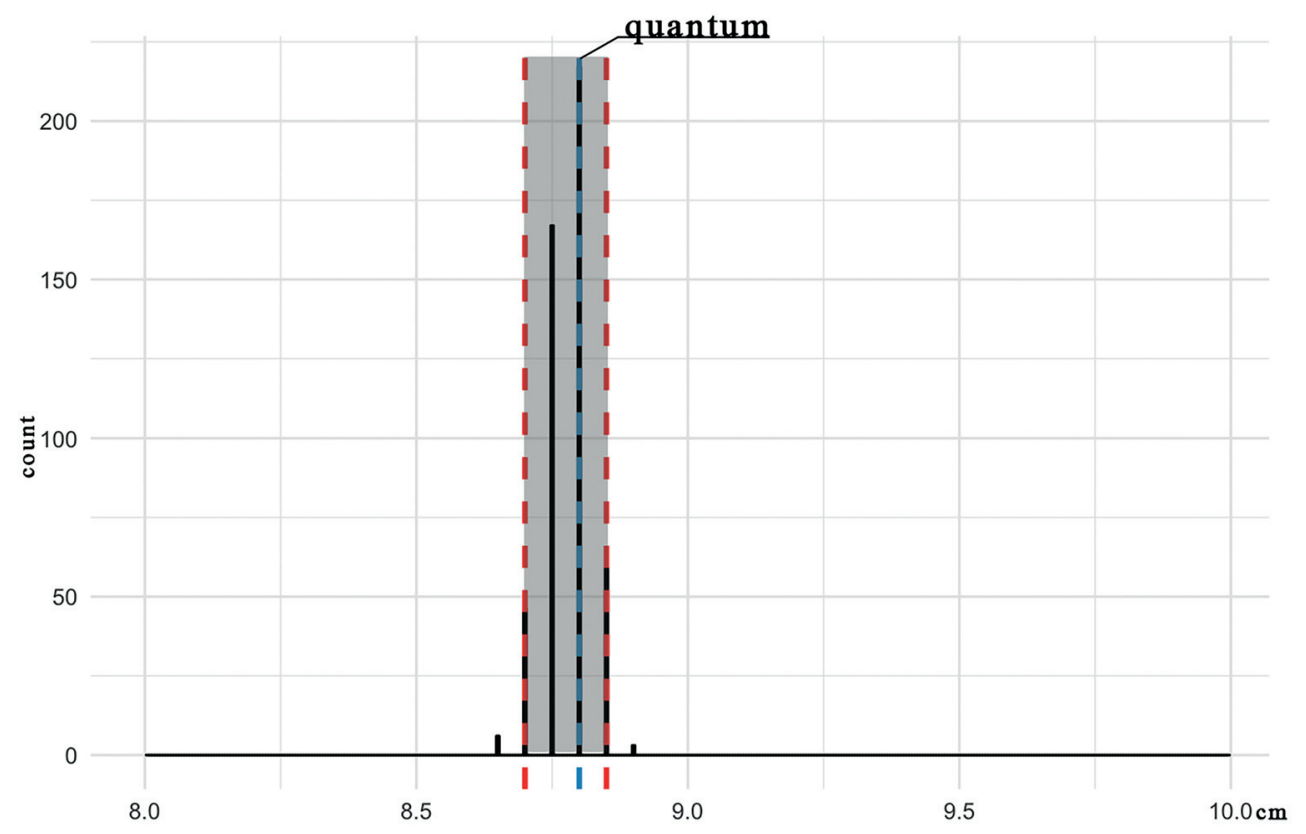

8. Bootstrap confidence intervals of $95 \%$ for 500 samples from 8.7 to $8.85 \mathrm{~cm}$ (Plotted by: M. Kasiński).

density. The results are presented in the graph (Fig. 7), where the sum of the cosine values (score) is plotted against $(q=8.8)$, and its value of 5.65 is scientifically high for only twenty-four measurements.

After applying the cosine quantogram to the frieze data, the verification of estimated quantum is evaluated using the Monte Carlo simulations. Data which could be dominated by some outlier measurements are tested by the bootstrap method to construct confidence intervals - the estimation of the most possible range of quantum values (Fig. 8). From the original data 500 equal size samples are drawn with replacement. For each sample, after unrounding, the same cosine quantogram procedure is applied. Assuming $5 \%$ significance level, the quantum $8.8 \mathrm{~cm}$ for original data falls within the confidence interval. The bootstrap confidence interval is $8.70-8.85 \mathrm{~cm}$. Such an interval estimate of quantum is very narrow, around the highest peak on the original dataset. Therefore, we have more evidence for quantum around $8.8 \mathrm{~cm}$, and the risk of such quantum occurring by chance is very low. Specifically, in the cosine quantogram problem, the parameter distribution might be concentrated around a few quanta, which requires a cautious interpretation of confidence intervals.

\section{Acknowledgements}

The authors want to thank Henryk Meyza, who was the Director of the Polish Archaeological Mission until 2019, for his patience and assistance, and Maciej Kasiński for the implementation of the cosine quantogram formula and the bootstrap confidence intervals 
in the $\mathrm{R}$ programming language. The application of the cosine quantogram method in the archaeological studies was financed by the National Science Centre (NCN), Poland, with the Etiuda doctoral scholarship (no. 2015/16/T/HS3/00020). Also, the study of architectural order and town planning of ancient Paphos were supported by the NCN grant (no. 2019/35/B/HS3/02296).

\section{References}

Brzozowska, A. 2016: A Pseudo-Ionic Blocked-out Capital at Nea Paphos, EtudTrav XXIX, 43-65

Brzozowska-Jawornicka, A. 2018: Reconstruction of the Western Courtyard of the 'Hellenistic House' in Nea Paphos, Cyprus, [in:] Bąkowska-Czerner, G., Czerner, R. (Eds), Greco-Roman Cities at the Crossroads of Cultures. The $20^{\text {th }}$ Anniversary of PolishEgyptian Conservation Mission Marina el-Alamein, Oxford, 57-73

Brzozowska-Jawornicka, A. 2021: 'Hellenistic' House in Nea Paphos, Cyprus - A First Summary of Its Architecture, EtudTrav XXXIV, 93-121

Charalambous, E. 2012: Technología kataskevís ton epidapédion psifidotón tis Kýprou, Nicosia

Coulton, J.J. 1975: Towards Understanding Greek Temple Design: General Considerations, ABSA 70, 59-99

Czerner, R. 2009: The Architectural Decoration of Marina el-Alamein, BAR-IS 1942, Oxford

Daszewski, W.A. 1985: Researches at Nea Paphos 1965-1984, [in:] Karageorghis, V. (Ed.), Archaeology in Cyprus 1960-1985, Nicosia, 277-291

Daszewski, W.A. 1990: Nea Paphos 1989, PAM I, 35-36

Daszewski, W.A. 1991: Nea Paphos 1990 Report, PAM II, 78-84

Daszewski, W.A. 1992a: Nea Paphos 1991, RDAC 1992, 251-254

Daszewski, W.A. 1992b: Nea Paphos 1991, PAM III, 59-67

Daszewski, W.A., Michaelides, D. 1988: Mosaic Floors in Cyprus, Ravenna

Daszewski, W.A., Sztetyło, Z. 1988: La région de Maloutena avant la construction de la Villa de Thésée, RDAC 1988, 195-203

Dinsmoor, W.B. 1961: The Basis of Greek Temple Design: Asia Minor, Greece, Italy, [in:] Susini, G. (Ed.), Atti del settimo congresso internazionale di archeologia classica I, Roma, 355-368

Dörpfeld, W. 1890: Metrologische Beiträge, Das äginäisch-attische Mass-System, MDAIA $15,167-187$

Guimier-Sorbets, A.-M., Michaelides, D. 2009: Alexandrian Influences on the Architecture and Decoration of the Hellenistic Tombs of Cyprus, [in:] Michaelides, D., Kassianidou, V., Merrillees, R.S. (Eds), Egypt and Cyprus in Antiquity, Oxford, 216-233

Hales, S. 2003: The Roman House and Social Identity, Cambridge

Hellmann, M.-Ch. 2002: L'architecture grecque, vol. 1, Les principes de construction, Paris

Hirsch, A.P. 2013: Ancient Egyptian Cubits - Origin and Evolution, unpublished PhD thesis, University of Toronto, Toronto 
Iversen, E. 1990: Metrology and Canon, MDAIK 46, 113-125

Jashemski, W.F. 1993: The gardens of Pompeii, Herculaneum and the villas destroyed by Vesuvius, vol. 2. Appendices, New Rochelle

Karageorghis, V. 1988: Chronique des fouilles et découvertes archéologiques à Chypre en 1987, BCH 112/2, 793-855

Karageorghis, V. 1989: Chronique des fouilles et découvertes archéologiques à Chypre en 1988, BCH 113/2, 789-853

Kasiński, M. 2019: Analysis of quantum in archaeological data with cosine quantogram and related statistical methods, https://zenodo.org/record/2566606\#.YdK2D2jMJPY, DOI: 10.5281/zenodo.2566606 (accessed September 19, 2020)

Kendall, D.G. 1974: Hunting Quanta, PTRS 276, 231-366

Majcherek, G. 1995: Alexandria 1994. Archaeological Excavations, PAM VI, 11-20

Majcherek, G. 1997: Alexandria. Kom el-Dikka Excavations 1995-1996, PAM VIII, 17-31

Majcherek, G. 2000: Kom el-Dikka Excavations, 1998/99, PAM XI, 27-38

McKenzie, J. 1990: The Architecture of Petra, Oxford

McKenzie, J.S. 2001: Keys from Egypt and the East: Observations on Nabataean Culture in the Light of Recent Discoveries, BASOR 324, 97-112

McKenzie, J. 2007: The Architecture of Alexandria and Egypt c. 300 BC to AD 700, New Haven-London

Medeksza, S. 1998: Willa Tezeusza w Nea Pafos na Cyprze: powstanie i fazy rozwoju, [in:] Daszewski, W.A., Meyza, H. (Eds), Cypr w badaniach polskich. Materiały z sesji naukowej zorganizowanej przez Centrum Archeologii Śródziemnomorskiej UW im. prof. K. Michałowskiego, Warszawa 24-25 luty 1995, Warszawa, 25-50

Meyza, H. 2015: Nea Paphos. Seasons 2012 and 2013, PAM XXIV/1, 443-452

Meyza, H., Daszewski, W.A., Brzozowska, A., Michalska, J., Rądkowska, J.K., Więch, M. 2012: Nea Paphos. Season 2009, PAM XXI, 407-422

Meyza,H., Romaniuk, M.M, Więch, M. with appendices by Mazanek-Somerlik, D., Więch, M. 2017: Nea Paphos. Seasons 2014 and 2016, PAM XXVI/1, 399-428

Meyza, H., Słowińska, M., Tybulewicz, R., Woźniak, M. 2014: Nea Paphos: Seasons 2010 and 2011, PAM XXIII/1, 391-402

Mitford, T.B. 1971: The Inscriptions of Kourion, Philadelphia

Młynarczyk, J. 1990: Nea Paphos in the Hellenistic Period, Nea Paphos III, Varsovie

Morvillez, E. 2018: The Garden in the Domus, [in:] Jashemski, W.F., Gleason, K.L., Hartswick, K.J., Malek, A.-A. (Eds), Gardens of the Roman Empire, Cambridge, $17-71$

Müller-Wiener, W. 2004: Greckie budownictwo antyczne, trans. D. Gorzelany-Nowak, Kraków

Nielsen, I. 1994: Hellenistic palaces: tradition and renewal, Aarhus

Pakkanen, J. 2002: Deriving ancient foot units from building dimensions: a statistical approach employing cosine quantogram analysis, [in:] Burenhult, G., Arvidsson, J. (Eds), Archaeological Informatics: Pushing the Envelope. Computer Applications 
and Quantitative Methods in Archaeology. Proceedings of the 29th Conference, Gotland, April 2001, BAR-IS 1016, Oxford, 501-506

Pakkanen, J. 2004: The Temple of Zeus at Stratos: New Observations on the Building Design, ARCTOS, Acta Philologica Fennica XXXVIII, 95-121

Pakkanen, J. 2013: Classical Greek Architectural Design: a Quantitative Approach, PMFIA 18, Helsinki

Papageorghiou, A. 1990: Chronique des fouilles et découvertes archéologiques à Chypre en 1989, $B C H$ 114/2, 941-985

Pensabene, P. 1993: Elementi architettonici di Alessandria e di altri siti egiziani, Roma

Pesce, G. 1950: Il "Palazzo delle Colonne" di Tolemaide di Cirenaica, Roma

Riemann, H. 1935: Zum griechischen Peripteraltempel. Seine Planidee und ihre Entwicklung bis zum Ende des 5. Jhds, Düren

Ronczewski, K. 1927: Description des chapiteaux corinthiens et variés du musée gréco-romain d'Alexandrie (Égypte), BSAA Suppl. 22, Riga

Stucchi, S. 1975: Architettura Cirenaica, MAL IX, Roma

The Metropolitan Museum of Art 2012: The Metropolitan Museum of Art Guide, New Haven, Conn. 2012

Wilson-Jones, M. 2000: Doric Measure and Architectural Design 1: The Evidence of the Relief from Salamis, AJA 104, 73-93

Wright, G.R.H. 1992: Ancient building in Cyprus, Leiden-New York-Köln

Zignani, P. 2010: Le temple d'Hathor à Dendara: Relevés et étude architectural, Cairo 


\section{ÉTUDES et TRAVAUX XXXIV / 2021}
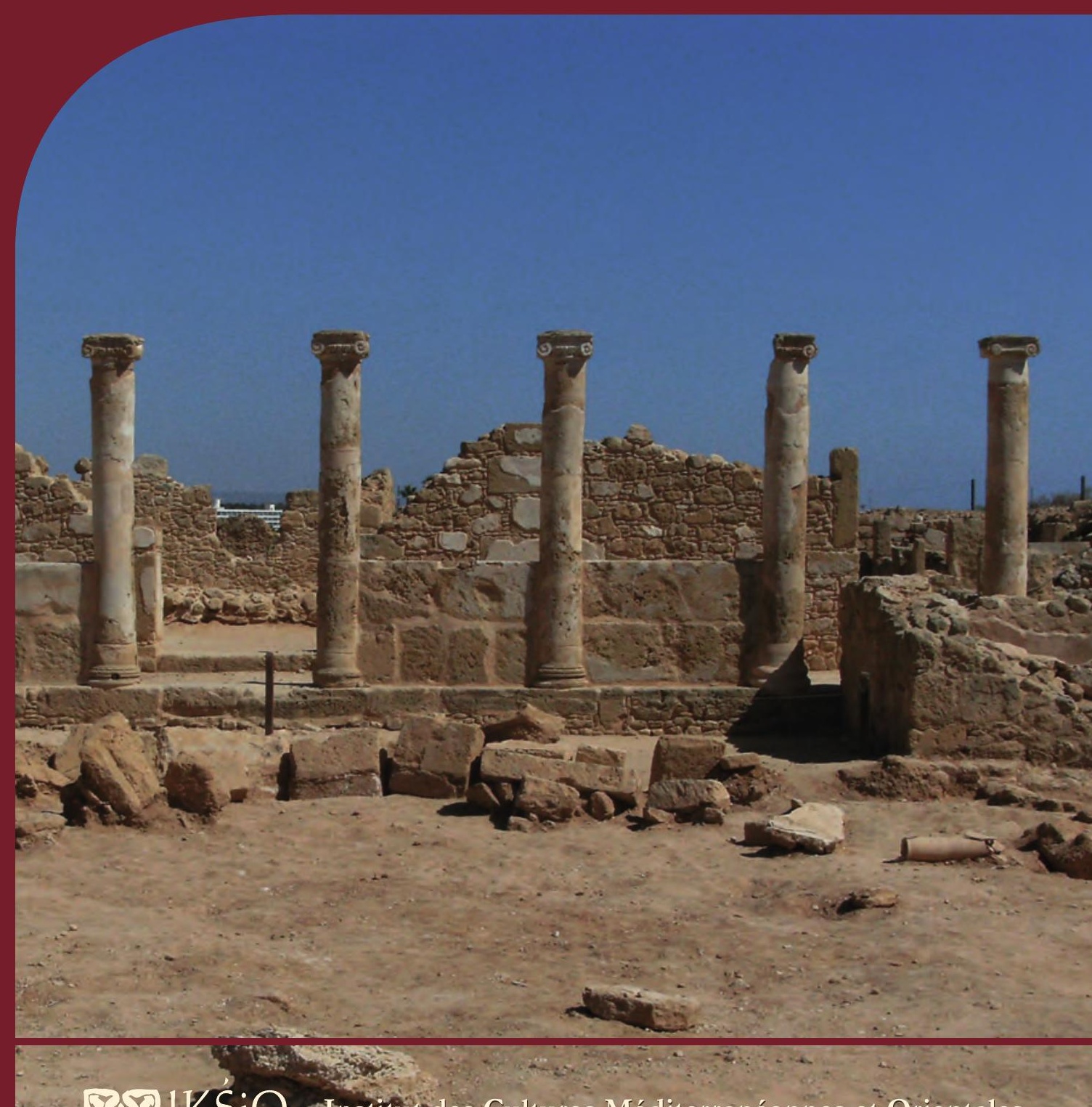

W $92 \mathrm{HKSiO}$ Institut des Cultures Méditerranéennes et Orientales

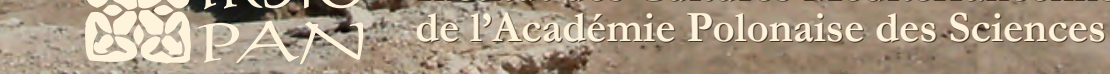

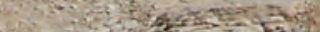

Q 
COMITÉ DE RÉDACTION SCIENTIFIQUE

Maciej Makowski - rédacteur en chef

Jadwiga Iwaszczuk - rédacteur

Katarzyna Kapiec - secrétaire de la rédaction

Henryk Meyza - rédacteur thématique du volume

CONSEIL SCIENTIFIQUE DU JOURNAL

M. Kobusiewicz (IAE PAN, Warszawa)

E. Laskowska-Kusztal (IMOC PAS, Warszawa)

D. Michaelides (University of Cyprus, Nicosia)

J.Ch. Moretti (IRAA-MOM, Université de Lyon 2/CNRS)

D. Raue (Ägyptisches Museum der Universität Leipzig)

P. Reynolds (ICREA, España)

D. Welsby (British Museum, London)

COMITÉ SCIENTIFIQUE DE LECTURE

la liste des membres du comité est accessible en ligne sur

http://www.etudesettravaux.iksiopan.pl

RÉDACTION TECHNIQUE

Marta Kaczanowicz

REVUE DES TEXTES EN ANGLAIS

Jo Harper 
ÉTUDES et TRAVAUX XXXIV 
INSTYTUT KULTUR ŚRÓDZIEMNOMORSKICH I ORIENTALNYCH POLSKIEJ AKADEMII NAUK

\title{
STUDIA i PRACE
}

\section{XXXIV}

\author{
GoIKSiO \\ QSO PAN \\ WARSZAWA \\ 2021
}


INSTITUT DES CULTURES MÉDITERRANÉENNES ET ORIENTALES DE L’ACADÉMIE POLONAISE DES SCIENCES

\section{ÉTUDES et TRAVAUX}

XXXIV

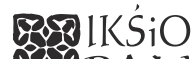

EOSPAN

VARSOVIE

2021 
Publication scientifique financée dans le cadre du programme du Ministre de la Science et de l’Éducation Supérieure

« Programme National de Développement de l’Humanistique » pour les années 2016-2021 (projet no 3bH 150099 83)

\title{
(1) NARODOWY PROGRAM ROZWOJU HUMANISTYKI
}

\author{
Copyright $(C)$ \\ Instytut Kultur Śródziemnomorskich i Orientalnych PAN \\ et les Auteurs \\ Warszawa 2021
}

ISSN 2084-6762

(jusqu'en 2011 : 0079-3566)

e-ISSN 2449-9579
Version première en papier, imprimée en Pologne - 150 copies
Version électronique accessible sur
http://www.etudesettravaux.iksiopan.pl

Édition: Polskie Towarzystwo Historyczne et Wydawnictwo Neriton, Warszawa

Conception générale de la couverture : J. Iwaszczuk

Photographie de couverture : Phot. A. Brzozowska-Jawornicka

(Le portique ionique est, péristyle de la Maison « hellénistique », Nea Paphos) 


\section{Table des matières}

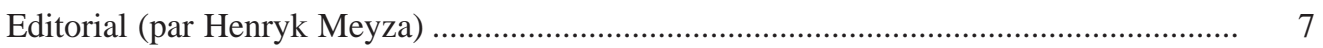

Marta BaJTLER

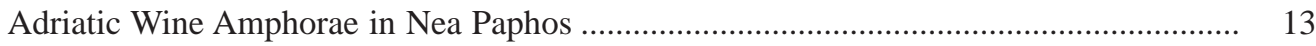

Claire Balandier, Jolanta MlynarczyK

The Temple and Its Surroundings on Fabrika Hill, Paphos: Preliminary Results

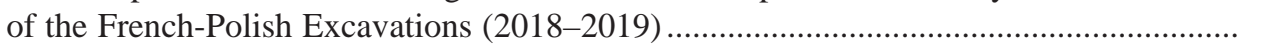

Grażyna BĄKowska-Czerner, Rafal CzERner

The Shell Motif in the Culture and Architecture of the Ancient Town of Marina el-Alamein in Egyp

AleKsandra BrzozowsKa-JaWornicKa

'Hellenistic' House in Nea Paphos, Cyprus - A First Summary of Its Architecture.

AleKsandra BrzozowsKa-JaWORnicKA, AnNa KuBICKA-SowińsKa

In Search of the Module in the Architectural Design of the 'Hellenistic'

House in Nea Paphos, Cyprus

RoKsana HaJduga

Kushite Stamp Impressions from Selib 2, Sudan

ERSIN HusSEIN

Mapping Metal Rich Roman Cyprus: The Case for Object-Centred Approaches

BARBARA LICHOCKA

Villa of Theseus at Nea Paphos (Cyprus). Fourth-Early Fifth Century Numismatic

Evidence for Architectural Transformations and Seismic Events

VASiliki Lysandrou, Demetrios Michaelides

Wall Paintings in Ancient Cyprus: The Hellenistic and Roman Tombs of Paphos

and Its Region

ADAM ŁAJTAR

A Weight of Seleucia in Pieria in Nea Paphos

Diana MroczeK

Ancient Portrait Busts of Marcus Aurelius in the National Museum in Poznań 
Brandon R. Olson, R. Scott Moore, Thomas Landvatter, Justin Stephens

Pyla-Vigla: A Case Study Assessing the Imperial Strategies of the Hellenistic

Diadochoi in Cyprus

Patrizio Pensabene, Eleonora Gasparini

Colonnaded Hall in Kourion: How the Oecus Corinthius Was Interpreted in the Roman

Houses of Cyprus

Monika Rekowska, Demetrios Michaelides, Skevi Christodoulou, JAKUB KANISZEWSKI

Adopting Roman Habits - The Baths in the House of Orpheus in Nea Paphos

as a 'Troublesome' Case Study?

MARCIN M. ROMANIUK

Terracotta Pipelines at Maloutena: Remarks on the Water System in the

Residential District of Ancient Nea Paphos, Cyprus

363

ABRÉVIATIONS

407 